\title{
EFFECT OF SOLID STATE FERMENTATION ON NUTRITIONAL CONTENT AND EVALUATION OF DEGRADABILITY IN CACTUS PEAR ${ }^{1}$
}

\author{
TAMIRES CARVALHO DO SANTOS ${ }^{2}$, GLEIZA ALVES DINIZ², AILA RIANY DE BRITO ${ }^{3}$, \\ AURELIANO JOSÉ VIEIRA PIRES ${ }^{4}$, MARCELO FRANCO ${ }^{*}$
}

\begin{abstract}
The process of protein enrichment of cactus pear (Nopalea cochenillifera (L.) Salm Dyck) by solid state fermentation with the use of Aspergillus niger and Rhyzopus sp. was studied for improving the nutritional value of this cactus species for use as animal feed. The experiments were conducted in the Agroindustrial Waste Laboratory of State University of Southwest Bahia (Brazil). To this end, we have evaluated the effects of biotransformation on the levels of protein, cellulose, hemicellulose, and lignin, as well as the potential degradability. Bioconversion was carried out using cactus pear as the only substrate, without supplementation with nitrogen, mineral and vitamin sources. The fermentation with Aspergillus niger promoted a 78\% increase in/of protein content and reductions of cellulose, hemicellulose, and lignin of 40\%, 36\%, and $28 \%$, respectively. Degradability, in turn, was observed to have increased by $66 \%$ after $240 \mathrm{~h}$. On the other hand, the fermentation with Rhyzopus sp. was less efficient, with a $69 \%$ increase in protein content, and reductions in cellulose, hemicellulose, and lignin contents of $30 \%, 28 \%$, and $18 \%$. In turn, degradability was seen to have increased by $51 \%$. The fermentation of cactus pear by Aspergillus niger and Rhyzopus sp. exhibited the protein enrichment and increased protein degradability of this Cactaceae. Moreover, this is the most ever efficient micro-organism used in bioconversion. Based on the results, bioconversion of cactus is an excellent alternative to ruminant feeding in arid or semi-arid land.
\end{abstract}

Keywords: Aspergillus niger. Rhyzopus sp.. Solid state fermentation. Semi-arid Land. Ruminant feeding. Nopalea cochenillifera (L.). Salm-Dyck.

\section{EFEITO DA FERMENTAÇÃO EM ESTADO SÓLIDO NO CONTEÚDO NUTRICIONAL E AVALIAÇÃO DA DEGRADABILIDADE NA PALMA FORRAGEIRA}

\begin{abstract}
RESUMO - O processo de enriquecimento protéico da palma (Nopalea cochenillifera (L.) Salm-Dyck) por fermentação em estado sólido com auxílio dos fungos filamentosos Aspergillus niger e Rhyzopus sp. foi estudado visando a elevação dos teores nutricionais para o uso como ração animal. Os experimentos foram realizados no Laboratório de Resíduos Agroindustrial da Universidade Estadual do Sudoeste da Bahia (UESB). O efeito da fermentação em estado sólido sobre a palma forrageira foi avaliado comparando os teores de proteína, celulose, hemicelulose e lignina, além da degradabilidade potencial, com os valores in natura. A bioconversão foi realizada utilizando como único substrato a palma forrageira e água, sem a suplementação de fontes alternativas de nitrogênio, minerais ou vitaminas. O fungo Aspergillus niger elevou os teores proteicos em aproximadamente $78 \%$ e promoveu a redução nos teores de celulose, hemicelulose e lignina em aproximadamente $40 \%$, $36 \%$ e $28 \%$, respectivamente. Por sua vez essa biotransformação elevou a degradabilidade potencial em $66 \%$ após 240 h. Enquanto que o fungo Rhyzopus sp. demonstrou ser menos eficiência no enriquecimento proteico, com um aumento de aproximadamente $69 \%$, e a redução no teores de celulose, hemicelulose e lignina de $30 \%$, $28 \%$ e $18 \%$. Ainda para este fungo a degradabilidade potencial teve uma elevação de aproximadamente $51 \%$. Portanto a fermentação da palma forrageira com auxílio dos fungos filamentosos Aspergillus niger e Rhyzopus $s p$. promoveram um enriquecimento nos teores proteicos desta cactacea além de elevar a sua degradabilidade potencial. Com base nesses resultados, a bioconversão da palma forrageira empregando o método de fermentação em estado sólido pode ser uma excelente alternativa na alimentação de ruminantes em terras áridas ou semiáridas.
\end{abstract}

Palavras-chave: Aspergillus niger. Rhyzopus sp.. Fermentação em Estado Sólido. Regiões Semiáridas. Alimentação de Ruminantes. Nopalea cochenillifera (L.). Salm-Dyck.

\footnotetext{
*Corresponding author

${ }^{1}$ Received for publication in 12/03/2014; accepted on 30/04/2015.

Trabalho de dissertação em Ciências Ambientais do primeiro autor.

${ }^{2}$ Mestre em Ciências Ambientais, UESB, Caixa Postal 40, 457000-000, Itapetinga-BA.

${ }^{3}$ Mestre em Engenharia e Ciência de Alimentos, UESB, Caixa Postal 40, 45700-000, Itapetinga-BA.

${ }^{4}$ Departamento de Tecnologia Rural e Animal, UESB, Caixa Postal 40, 457000-000, Itapetinga-BA.

${ }^{5}$ Departamento de Ciências Exatas e Tecnológicas, UESC, Km 16, 45662-900, Ilhéus-BA; marcelofranco@pq.cnpq.br.
} 


\section{INTRODUCTION}

The dairy industry in northeastern of Brazil is characterized by the presence of small- and mediumsized breeders. The climatic conditions resulting from periodic droughts lead to scarce, and irregularity rainfall associated and high temperatures, affecting the availability and quality of fodder for livestock. Reduced milk production or the need for increasing the supply of commercial feed concentrates for animals so as to meet their nutritional requirements decreases the profitability of the sector (WANDERLEY et al., 2012).

Two forage palm species are grown in northeastern Brazil as serve as alternatives to animal feed: Opuntia ficus-indica (L.) Mill - giant palm - and Nopalea cochenilifera (L.) Salm-Dyck - cactus pear - the former being more studied and cultivated than the latter. The physiological mechanisms of cactus pear make it one of the plants most adapted to the ecological conditions of the arid and semiarid regions worldwide; thus it has adapted with relative ease to the semi-arid zone of northeastern Brazil. As a result, forage palm exhibits high yields of dry matter content per unit area, non-fiber carbohydrates and digestibility coefficient of dry matter. Also, it forms the basis of animal feed during the shortage of forage (BISPO et al., 2007; CHIACCHIO et al., 2006; OLIVEIRA et al., 2010).

The nutritional value of fungi-enriched forage is almost equal to or higher than that found in commercial concentrates used during the dry season, once it is rich in microbial protein, minerals and other nutraceutical compounds (DARWISH et al., 2012). Thus, the bioconversion of forage palm is an alternative to aggregate value, increase livestock production and relieve the supply chain, considering the frequent price increasing of industrial concentrates used in animal dietary supplementation (ARAÚJO et al., 2005; ARAÚJO et al., 2008).

The Food and Agriculture Organization (FAO) acknowledges the potential of palm and its importance in contributing to the development of arid and semiarid regions, in particular in developing countries, through the economic exploitation of the various species, with great consequences for the environment and food security (CHIACCHIO et al., 2006).

The bioconversion of forage palm through the use of technology adapted to rural conditions is an alternative to establish an economically viable process aimed at minimizing the severe regional distortions that affect the country. Nonetheless, protein conversion efficiency depends on factors such as temperature, oxygen supply, micro-organisms, and nutrient availability (GALEMBECK et al., 2009; GHORAI et al., 2009). Filamentous fungi, especially some species of the genus Aspergillus and Rhizo- pus are consider the most promising for biomass because they raise protein content as well as produce proteins with specific catalytic activity with high digestibility and without toxic substances (SINGHANIA et al., 2009).

The objective of this work was to study the effects of time on fermentation in solid-state cactus pear using Aspergillus niger and Rhizopus sp. on protein enrichment and evaluate the percentage reductions of polymers such as cellulose, hemicellulose, and lignin, as well as the increased in vivo digestibility.

\section{MATERIAL AND METHODS}

Cactus pear (Nopalea cochenillifera (L.) Salm -Dyck) was collected at the experimental field of Universidade Estadual do Sudoeste da Bahia (UESB), more precisely at the campus of ItapetingaBahia, Brazil. Samples were prepared at the Laboratory of Agro-Industrial Wastes (LABRA). Samples were cut, dried in a drying oven at $105^{\circ} \mathrm{C}$ for $24 \mathrm{~h}$. The dry mass was quantitated by using infrared equipment (ID200, MARTE), and ground in a Willey mill (ACB LABOR) so as to reach particle sizing of $2 \mathrm{~mm}$.

After the drying process, the water activity was 0.457 as measured by a water activity determiner (BASEQ, AQUALAB). This material was used as the fermentation substrate after the addition of sterile distilled water for reaching a water activity of 0.931

The filamentous fungi Aspergillus niger and Rhizopus sp. cultivated at the Laboratory of AgroIndustrial Waste Reuse were used in the fermentation of cactus pear. Microorganisms were cultured on a PDA medium (HIMEDIA ) for seven days at $35^{\circ} \mathrm{C}$. Spores were collected using $0.01 \% \mathrm{v} / \mathrm{v}$ Tween -80 solution (VETEC) and were counted in a Neubauer chamber, with the aid of a binocular microscope (L1000, BIOVAL).

Trials were conducted in Erlenmeyer flasks containing $40 \mathrm{~g}$ of inoculated cactus pear with a suspension containing $10^{8}$ spores $\mathrm{g}^{-1}$ of the substrate. Fermentation was carried out in a bacteriological greenhouse with air circulation (SL 101, SOLAB) at $35^{\circ} \mathrm{C}$.

Chemical analyzes were performed as described by AOAC (1990). Using a conversion factor of 6.25 for total nitrogen in protein, Kjeldahl method was applied to determine the total protein content. The analysis of dry matter was performed in greenhouse conditions with air circulation at $50^{\circ} \mathrm{C}$ for 72 h.

In order to determine the total fibrous composites, the sample was subjected to a pre-treatment with $8 \mathrm{M}$ urea (Sigma) and $\alpha$-amylase $(15 \mu \mathrm{L}$ - Sig$\mathrm{ma}$ ) to catalyze the hydrolysis of starch and prevent gelatinization. After that, the hydrolyzed sample was 
treated with neutral detergent for separating the insoluble fibers consisting of cellulose, hemicellulose, and lignin and lignified protein fraction. Next, the precipitate was subjected to drying in an oven at 105 ${ }^{\circ} \mathrm{C}$, for $8 \mathrm{~h}$ and was weighed. In the determination of acid detergent fiber, a specific acid detergent was used to solubilize the cellular content and hemicellulose, as well as most of the insoluble protein. An insoluble residue almost entirely constituted of lignin and cellulose was obtained (lignocellulose). Lignin was hydrolyzed with sulfuric acid $(72 \% \mathrm{v} / \mathrm{v})$, and only cellulose and insoluble minerals were left in the crucible.

Incineration determined the mineral content of cactus pear in a muffle furnace (FORNITEC- 2 DM.) at $550^{\circ} \mathrm{C}$. The ether extract content from cactus pear samples $(2 \mathrm{~g})$ was determined by gravimetric analysis using a Soxhlet-type extractor (MA-491, SPLABO) and petroleum ether as a solvent.

The in situ degradability trial was conducted in crossbred cattle (Dutch $x$ Zebu) fistulated in the rumen. The animals were kept in a pasture system and were fed a diet composed of forage in the form of Brachiaria decumbens as $20 \% \mathrm{w} / \mathrm{w}$ of the concentrate on a dry matter basis. The animals were supplemented mineral salt at libitum.

The fermented cactus pear samples were dried in a greenhouse with ventilation (SL 102, SOLAB) at $55^{\circ} \mathrm{C}$ for $72 \mathrm{~h}$ and were ground in a Willey mill so as to reach particle sizing of $2 \mathrm{~mm}$. Five grams of each sample were weighed into polyester bags (dimensions of $5 \times 10 \mathrm{~cm}$ and $50 \mu \mathrm{m}$ porosity) yielding a ratio of $20 \mathrm{mg}$ of sample per $\mathrm{cm}^{-2}$ of the bag. The bags were sealed, placed in the ventral area of the rumen, and fixed externally using a nylon rope (MATHIS et al., 2001). The period of incubation was $240 \mathrm{~h}$. After the rumen had been removed, the bags were washed in running water and were immediately transferred to a greenhouse at $60^{\circ} \mathrm{C}$, where they remained for $24 \mathrm{~h}$. The bags were afterward dried at $105^{\circ} \mathrm{C}$ for $45 \mathrm{~min}$ to determine degradability.

The model described by Orskov and McDonald (1979) was used to adjust the mean values of dry matter intake of each diet from the following equation:

$$
\mathrm{P}=\mathrm{a}+\mathrm{b} *\left(1-\exp ^{\mathrm{c} * t}\right)
$$

Where $\mathbf{P}$ denotes degradability, $\mathbf{t}$ is incubation time, a means soluble substrate completely degradable rapidly and washed out of the bag, $\mathbf{b}$ is insoluble substrate - but potentially degradable - and c indicates the rate constant function $\mathbf{b}$.

The completely randomized design was used with three treatments and four replications. Data were subjected to analysis of variance using the SAEG software, version 8.0 (2008), whereas the means were compared by SNK test (StudentNewman-Keuls) at $5 \%$ probability $(p<0.05)$.

\section{RESULTS AND DISCUSSION}

The protein or nutritional enrichment provided by fermentation in solid state of cactus pear (Nopalea cochenillifera (L.) Salm-Dyck) using Aspergillus niger and Rhizopus sp. promoted increases in the total protein contents of $78 \%$, and $69 \%$, respectively, reaching protein levels of $9.1 \%$, and 8.6 $\%$ after $192 \mathrm{~h}$ of fermentation (Figure 1).

The decreased amount of protein observed after $192 \mathrm{~h}$ of fermentation in cactus pear can be assigned to a probable volatilization of the nitrogen and ammonia production, as reported by Araújo et al. (2008).

Protein enrichment was the result of increased microbial biomass, considering the absence of nitrogen sources. Ugwuanyi et al. (2008) have reported the same effect. As reported by $\mathrm{Hu}$ et al. (2012), the supplementation with $2.5 \%$ of nitrogen source is necessary to increase the protein content from 5-6\% to $16-20 \%$.

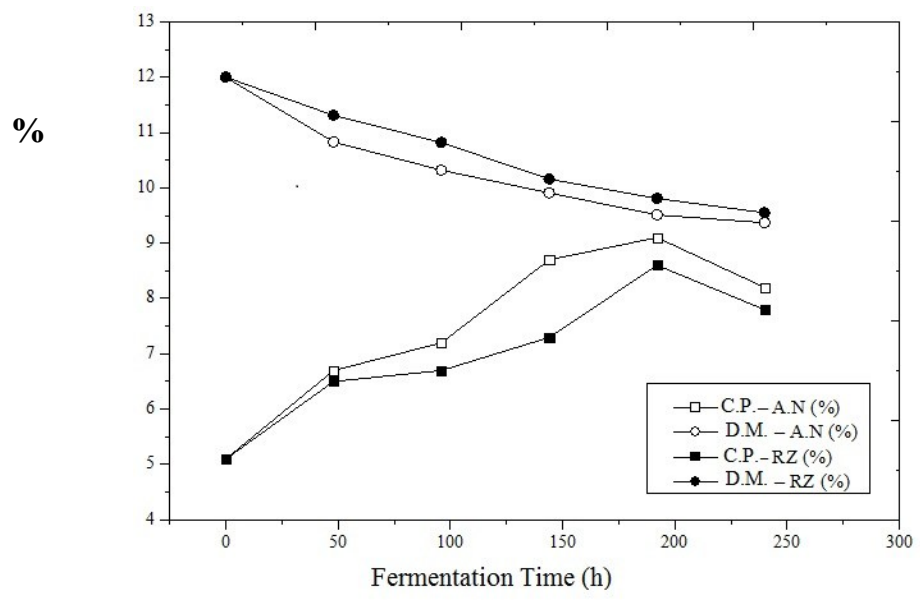

Figure 1. Effect of solid state fermentation in content protein (CP) and dry matter (DM) the cactus pear by Aspergillus niger (AN), and Rhizopus sp. (RZ) 
The ability of Aspergillus niger to produce enzymes that catalyze the hydrolysis of polymers such as cellulose, hemicellulose, and lignin forming the framework of vegetable matrices enables the production of metabolites required for microbial growth. Some of the synthesized enzymes are amyloglucosidase, endoglucanase, endoglucanase complex and exoglucanase, laccase, xylanase, peroxidase and manganese peroxidase (AHMAD et al., 2013; SANTANA et al., 2012; SANTOS et al., 2012; SANTOS et al., 2013).

The reported studies concerning the protein enrichment of forage have on the whole used giant palm - Opuntia ficus-indica (L.) Mill - therefore, few are the studies involving cactus pear - Nopalea cochenilifera (L.) Salm-Dyck. The protein enrichment of giant palm (Opuntia ficus-indica (L.) Mill) using an inoculum concentration of 1\% w/w Saccharomyces cerevisiae and $36 \mathrm{~h}$ of fermentation allowed for a protein content increase from $4.0 \%$ to $9.22 \%$, that is, an increase of $131 \%$. The shorter fermentation time used by these authors with a gain of protein content similar to that observed in this study can be, amongst other factors, assigned to the greater amount of Cactaceae and inoculum used in the fermentation process. In other studies, the fermentation of cactus pear using fungi allowed for increasing protein content at levels similar to those observed in sorghum $(10 \%)$ and grain corn $(9 \%)$, which are widely used as animal feed (ARAÚJO et al., 2005; ARAÚJO et al., 2008).

As per the example of forage palm, the bioconversion of agro-industrial waste and other sources has also been studied as to increase protein content and promote the nutritional enrichment of these materials for use in animal feed (DAWISH et al., 2012; OGUNJOBI et al., 2011; RUDRAVARAM et al., 2006).

Nonetheless, it is noteworthy that the optimization of parameters involved in bioconversion, such as humidity and pre-treatment of raw material, micro -organism species and amount of inoculum, temperature and fermentation time, $\mathrm{pH}$, particle size of the substrate, and additional nutrient sources should be evaluated so as to achieve greater efficiency in the process.

When evaluating the effect of different microorganisms in the protein enrichment of forage species (Digitaria decumbens Stent) widely used in Taiwan as animal feed, Hu et al. (2012) have verified an increase from $5.97-6.28 \%$ to $7.09-16.96 \%$ in protein content, which was determined by the type of microorganism isolated or used in the fermentation process. As regards the use of Aspergillus niger, the observed increase in protein content was 9.3\%, whereas the highest protein level was obtained with the use of Streptomyces vendargensis (isolate CL3). Also to a greater amount of the used forage species, supplementation of the culture medium with nitrogen sources and minerals has promoted a final protein content of the one used in the present study.

Synergistic effect was observed with the combination of Pleurotus ostreatus and Saccharomyces cerevisiae in the solid state fermentation of corn stalk, leading to a protein content increase from 3.6 to $11.8 \%$ (DARWISH et al., 2012).

The use of forage pre-treatment has promoted structural changes, making the lignin-cellulose fraction more accessible to hydrolytic enzymes, thus favoring microbial metabolism (HU et al., 2012).

According to Araújo et al. (2005), the concentration of Saccharomyces cerevisiae inoculum was the parameter that most influenced the $400 \%$ increase of protein content in giant palm (Opuntia ficus-indica (L.) Mill). As measured by these researchers, the maximum protein content of $26 \%$ was equal to or higher than those of oat bran $(25.8 \%)$, coarse wheat bran (15\%), babassu meal $(20.5 \%)$, coconut residue $(21.2 \%)$, cotton seed $(23.1 \%)$ and babassu bran $(24 \%)$.

In a study addressing the protein enrichment of rice bran with Aspergillus oryzae, the optimum conditions for the process were: $60 \%$ humidity, $28^{\circ}$ $\mathrm{C}, \mathrm{pH}$ 6.0, inoculum concentration of $10^{9}$ spores $\mathrm{g}^{-1}$ of substrate, and substrate particle size of $0.3 \mathrm{~mm}$. Amongst the various studied nitrogen sources, ammonium sulphate $(0.6 \% \mathrm{w} / \mathrm{w})$ has contributed to the maximum enrichment of protein $(24.30 \%)$ when compared to in natura bran (RUDRAVARAM et al., 2006).

The protein enrichment of corn cob was from $5.69 \%$ to $18.96 \%$, an increase of $258 \%$ using Bacillus stearothermophilus was maximum at $55^{\circ} \mathrm{C}, \mathrm{pH}$ 7.0 , aeration rate of $1.0 \mathrm{vvm}$ (volume of air per volume of the medium per minute), $5 \%$ inoculum $(\mathrm{v} / \mathrm{v})$, and supplementation with vitamin and mineral mixture (UGWUANYI et al., 2008).

The solid-state fermentation of cactus pear using Aspergillus niger and Rhizopus sp. has caused a decrease in the initial dry matter content $(12 \%)$ at $9.51 \%$ and $9.81 \%$, respectively, a decrease of $21 \%$ to $18 \%$ (Figure 1 ).

According to Burrows (1970), in the fermentation of glucose in aerobic medium, near half the amount of carbon is oxidized to $\mathrm{CO}_{2}$ to supply the energy necessary for microbial, whereas the other half is converted into cellular material.

The reduction of dry matter content consumption is revealed by the intake of fibrous components. After $120 \mathrm{~h}$ of fermentation by Aspergillus niger, the reductions of cellulose, hemicellulose and lignin were $40 \%, 36 \%$ and $28 \%$, respectively; and $47.83 \%$, $42.24 \%$ and $36.09 \%$ after $240 \mathrm{~h}$ of fermentation. On the other hand, the degradability potential was seen to have increased by $66 \%$ and $77 \%$ after $120 \mathrm{~h}$ and $240 \mathrm{~h}$ of biotransformation (Figure 2). 


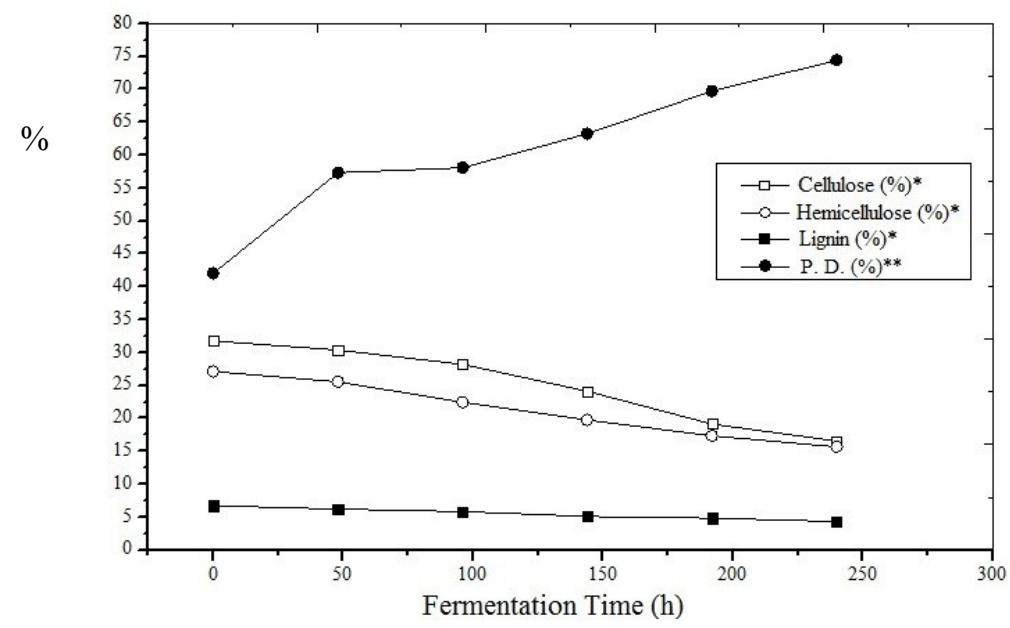

Figure 2. Effect of fermentation with Aspergillus niger cactus pear in levels of fibrous components and potential degradability (PD).

After cactus pear was subjected to fermentation with Rhizopuz sp. for $120 \mathrm{~h}$, the levels of cellulose, hemicellulose and lignin were seen to have reduced by $30 \%, 28 \%$, and $18 \%$, respectively. In turn, fermentation for $240 \mathrm{~h}$ led to decreases of $39.51 \%$, $36.89 \%$, and $26.48 \%$. The increase in degradability was $51 \%$ after $120 \mathrm{~h}$, reaching $58 \%$ by the end of the process (Figure 3).

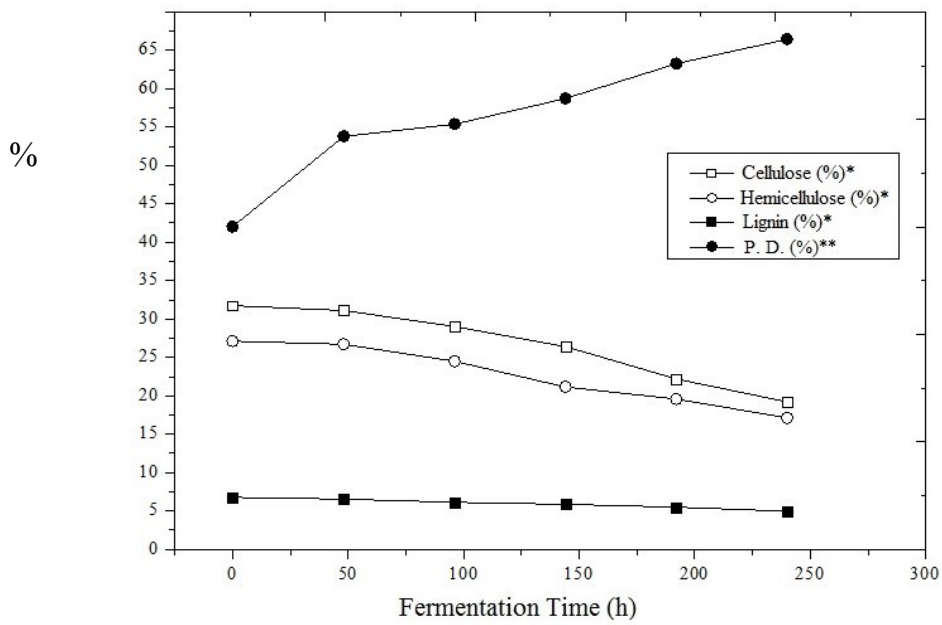

Figure 3. Effect of fermentation of palm girl with Rhizopuz sp. the levels of the fibrous components and potential degradability (PD).

The results of this study allows to conclude that Aspergillus niger is more efficient than Rhyzopus sp. in the enrichment cactus pear due to its higher dry matter intake - as demonstrated by the assessed fibrous components assessed - and the increased potential degradability and protein content (Figures 1-3).

A greater effect of fermentation in reducing cellulose (51\%), hemicellulose $(46 \%)$ and lignin $(49 \%)$ was obtained by varying the amount of inoculum from Saccharomyces cerevisiae and the fermentation time of corn stalk with Pleurotus ostreatus (DARWISH et al., 2012). Nonetheless, a decrease in hemicellulose content $(37.71 \%)$ similar to the one used in the present study was evidenced with the fermentation of corn cob by Bacillus stearothermophilus (UGWUANYI et al., 2008).

An increase of approximately $21 \%$ in the in vitro digestibility of giant palm fermented with Saccharomyces cerevisiae was reported by Araújo et al. (2005). As for the forage species Digitaria decumbens Stent fermented with Streptomyces thermonitrificans (NTU-88), the in vitro digestibility has increased from 4 to $24.8 \%$, i.e., an increase of $500 \%$. This modification denotes the importance of a careful selection of micro-organisms and the fermentation conditions. Analyzes made in this study revealed increased degradability of biomass due to higher cell fiber degradation of cactus pear by the micro-organisms present in the rumen, and thereafter, a greater nutrient absorption. Studies show therefore that the biotransformation of the palm is an important source of animal feed.

As an example, a study conducted by Bispo et al. (2007) has shown that a $56.0 \%$ replacement of giant palm (Opuntia ficus indica, Mill) by elephant 
grass hay in the diet of sheep has increased the intake and utilization of nutrients. According to Torres et al. (2009), cactus pear can fully replace giant palm in diets for growing cattle once it does not change the intake the apparent digestibility of nutrients, reinforcing the potential of this Cactaceae as animal feed.

\section{CONCLUSION}

The fermentation of cactus pear by Aspergillus niger and Rhyzopus sp. exhibited the protein enrichment and increased protein degradability of this Cactaceae. Moreover, the Aspergillus niger organism is the most efficient when used in bioconversion. The increase in protein degradability was due to a reduction in the levels of the fibers. The observed increase in degradability demonstrates that the presence of fungal protein did not negatively affect the operation of rumen bacteria.

The protein enrichment of cactus pear is an alternative to the use of cereal grains and commercial concentrates like protein sources of high quality.

\section{ACKNOWLEDGEMENTS}

The authors are thankful to the Conselho Nacional de Desenvolvimento Científico e Tecnológico (CNPq), the Fundação de Apoio a Pesquisa do Estado da Bahia (FAPESB) and the Universidade Estadual do Sudoeste da Bahia (UESC), the Banco do Nordeste Brasileiro (BNB) for the granted financial assistance.

\section{REFERENCES}

AHMAD, Z.; BUTT, M. S.; RIAZ, M. Partial Purification and Charactrization of Xylanase produced from Aspergillus niger using Wheat Bran. Pakistan Journal of Agriculture Science, Faisalabad, v. 50, n. 3, p. 433-437, 2013.

Association of Official Analytical Chemists. Official methods of analysis. Association of Official Anlytical Chemists, Gaithersburg, MD. USA. 1990.

ARAÚJO, L. F. et al. Protein Enrichment of Cactus Pear (Opuntia ficus - indica Mill) using Saccharomyces cerevisiae in Solid-State Fermentation. Brazilian Archives of Biology and Technology, Curitiba, v. 48, special, p. 161-168, 2005.

ARAÚJO, L. F. et al. Enriquecimento protéico da palma forrageira com Saccharomyces cerevisiae para alimentação de ruminantes. Arquivo Brasileiro de Medicina Veterinária e Zootecnia, Belo Horizonte, v. 60, n 2, p. $401-407,2008$.

BISPO, S. V. et al. Palma forrageira em substituição ao feno de capim-elefante: Efeito sobre Consumo, digestibilidade e características de fermentação ruminal de ovinos. Revista Brasileira de Zootecnia, Viçosa, v. 36, n. 6, p. 1902-1909, 2007.

BURROWS, S. Baker's yeast. In: Rose, A.H. and Harrison, J.S. (ed.). The Yeasts Yeast technology. London, Academic Press. p. 349-419, 1970.

CHIACCHIO, F. P. B.; MESQUITA, A. S.; SANTOS, J. R. Palma forrageira: uma oportunidade econômica ainda desperdiçada para o semiárido baiano. Revista Bahia Agrícola, Salvador, v. 7, n. 3, p. 3949, 2006.

DARWISH, G. A. M. A.; BAKR, A. A.; ABDALLAH, M. M. F. Nutritional value upgrading of maize stalk by using Pleurotus ostreatus and Saccharomyces cerevisiae in solid state fermentation. Annals of Agricultural Science, Ain-Shams, v. 57, n. 1, p. 47$51,2012$.

GALEMBECK, F.; BARBOSA, C. A. S.; SOUSA, R. A. Aproveitamento Sustentável de Biomassa e de Recursos Naturais na Inovação Química. Química Nova, São Paulo, v. 32, n.3, p. 571-581, 2009.

GHORAI, S. et al. Fungal Biotechnology in Food and Feed Processing. Food Research International, Toronto, v. 42, n. 5-6, p. 577-587, 2009.

HU, C. C.; LIU, L. Y.; YANG, S. S. Protein enrichment, cellulase production and in vitro digestion improvement of pangolagrass with solid state fermentation. Journal of Microbiology, Immunology and Infection, Taiwan, v. 45, n. 1, p. 7-14, 2012.

MATHIS, C. P. A collaborative study comparing an in situ protocol with single time-point enzyme assays for estimating ruminal protein degradability of different forages. Animal Feed Science and Technology, Madrid, v. 93, n. 1, p. 31-42, 2001.

OLIVEIRA, F. T. et al. Palma forrageira: adaptação e importância para os ecossistemas áridos e semiáridos. Revista Verde de Agroecologia e Desenvolvimento Sustentável, Mossoró, v. 5, n. 4, p. $27-37,2010$.

OGUNJOBI, A. A.; MEJEHA, O. K.; FAGADE, O. E. Protein Enrichment of Brewery Spent Grains Using Aspergillus oryzae. AU Journal of Technology, Bangkok, v. 15, n. 1,p. 53-56, 2011.

ØRSKOV, E. R.; MCDONALD, J. The estimation of protein degradability in the rumen from incubation measurements weighted according to rate of 
passage. Journal of Agricultural Science, Toronto, v. 92 , n. 2, p. 499-503, 1979.

RUDRAVARAM, R. et al. Optimization of Protein Enrichment of Deoiled Rice Bran by Solid State Fermentation Using Aspergillus oryzae MTCC 1846. International Journal of Food Engineering, Rowland Heights, v. 2, n. 4, p. 1-14, 2006.

SANTANA, R .S. M. et al. Produção de amiloglucosidase utilizando como substrato a palma forrageira. Revista Caatinga, Mossoró, v. 25, n. 1, p. 188-193, 2012.

SANTOS, T. C. et al. Optimisation of solid state fermentation of potato peel for the production of cellulolytic enzymes. Food Chemistry, Reading, v. 133, n. 4, p. 1299-1304, 2012.

SANTOS, T. C. et al. Application of response surface methodology for producing cellulolytic enzymes by solid-state fermentation from the puple mombin (Spondias purpurea L.) Residue. Food Science and Biotechnology, Seoul, v. 22, n. 1, p. 1-7, 2013.

SINGHANIA, R. R. et al. Recent Advances in Solidstate Fermentation. Biochemical Engineering Journal, Illinois, v. 44, n. 1, p. 13-18, 2009.

TORRES, L. C. L. et al. Substituição da palmagigante por palma-miúda em dietas para bovinos em crescimento e avaliação de indicadores internos. Revista Brasileira de Zootecnia, Viçosa, v. 38, n. 11, p. 2264-2269, 2009.

UGWUANYI, J. O.; HARVEY, L. M.; MCNEIL, B. Protein enrichment of corn cob heteroxylan waste slurry by thermophilic aerobic digestion using Bacillus stearothermophilus. Bioresource Technology, Trivandrum, v. 99, n. 15, p. 6974-6985, 2008.

WANDERLEY, W. L. et al. Silagens e fenos em associação à palma forrageira para vacas em lactação. Consumo, digestibilidade e desempenho. Revista Brasileira de Saúde e Produção Animal, Salvador, v. 13, n. 3, p. 745-754, 2012. 